論文

\title{
Capillary Flow Properties of Lyotropic Liquid Crystalline Solution of Hydroxypropyl Cellulose in Acetic Acid
}

by

Shinichi Suto, Masahiko OHShIRo, Ryoko Ito, and Mikio Karasawa

Department of Polymer Chemistry, Faculty of Engineering, Yamagata

University, Jonan 4-3-16, Yonezawa, Yamagata 992

Viscoelastic properties of a lyotropic liquid crystal were determined with a capillary rheometer. So-called Bagley end correction was taken into consideration by using three dies which have the same diameter but different lengths. Measurements included the shear rate $(\dot{r})$ and concentration $(c)$ dependences of shear viscosity $(\eta)$ and three elastic parameters: Bagley end correction $(\nu)$, entrance pressure loss $\left(\Delta P_{\mathrm{ent}}\right)$, and die swell $(B)$. Shear viscosity behavior typcal of lyotropic liquid crystal was observed. The shear rate dependence of $\nu$ varied greatly with the change of concentration: $\nu$ increased with $\dot{r}$ at some concentrations, but decreased at other concentrations. $\eta$ and $\nu$ showed the maximum and minimum with respect to concentration. However, the concentration at the minimum was not identical with that for viscosity. $\Delta P_{\text {ent }}$ increased with shear rate at all concentrations. The concentration dependence of $\Delta P_{\text {ent }}$ was the same as that of viscosity. $B$ increased with shear stress only for isotropic solutions and decreased for anisotropic ones. The following relations have been found:

$$
\begin{array}{ll}
\nu & \propto B^{n} \\
\Delta P_{\text {ent }} & \propto B^{n \prime}
\end{array}
$$

where $n$ and $n^{\prime}$ are constants which depend on concentration.

\section{ヒドロキシプロピルセルロース/酢酸系ライオトロピック 液晶の毛管流動特性}

\author{
須藤 新一 ・大城 正彦・伊藤 亮子・唐沢 幹雄* \\ （原稿受理：1985年12月25日）
}

\section{1. 緒}

言

ケブラー緘維の成功以来, 多くの研究グループによりライオト

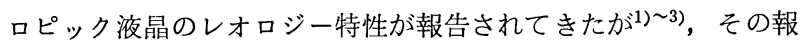
告のほとんどは粘性挙動に関するあのであった．高弾性率，高強 度の繊維むしくはフィルムを開発するためには, 液晶の粘性ばか りでなく弾性挙動をあ合わせて検討する必要があろう。そのよう

* 山形大学工学部高分子化学科 $\bar{T} 992$ 米沢市城南 4-3-16
な観点からすると, 粘・弾性挙動を同時に測定可能な Cone-plate 型レオメーターは非常に有用である。 それを用いて, Baird ら4), Porter $ら^{5)}$, White $ら^{6}$ ) はライオトロピック液晶の弾性挙動の解 明を精力的に行った。 しかし, 最近, White $ら^{7)}$, Baird $ら^{8)}$ によ り Cone-plate 型レオメーターを用いての弾性挙動の定量的測定 には, 困難さが伴うとの報告がされ始めた.さうに，上記レオメ 一ターでは実際の成形条件に近い高せん断における粘弾性挙動の 測定は, 二次流動が生じるため不可能である. 
そこで筆者らは, 比較的高せん断領域での粘弾性の測定可能な 毛管型粘度計に注目することにした。その粘度計によってあダイ の側面圧力を測定すると, 法線応力差を求得る ${ }^{9)}$. しかし, よ り簡便に，径が同じで，長さの異なる複数のダイを使用すること によってあ, 弾性パラメーターを測定するのは可能である ${ }^{10)}$. 具 体的には次に示す 3 種である.

1)ダイ入口に拉て,

a) Bagley 補正係数 $(\nu)$

b ) 流入圧損失 $\left(\Delta P_{\mathrm{ent}}\right)$

2)ダイ出口において,

a) ダイスウェル $(B)$

上記パラメーターのいずれあ第一法線応力差 $N_{1}$ に比べると, 弾性パラメーターとしての理論的根拠は明白でない。 また，それ らパラメーターは弾性ばかりでなく, 他の要因をむ含むと考えら れている11),12)。しかし，等方相溶液や融液では上記パラメーター のいずれあが $N_{1}$ と密接な相関を示すととが知られているので10), 液晶系についてもその弾性を上記パラメーターは定性的に反映す ると思われる。

てれまで, 毛管粘度計を用いての弾性パラメーターの測定は $B$ が主であった ${ }^{13)}$. また，Baird ら ${ }^{14)}$ はサーモトロピック液晶につ いてではあるが， $\Delta P_{\mathrm{ent}}$ とBを同時に测定し，それらパラメータ 一の相関を検討した. そして, 上記両パラメーター間に相関はな いと結論している.しかし, 弾性パラメーター間に相関が無いと 断定するには，なお測定データの集積が必要と思われる。

そこで本研究では，いわゆる Bagley 補正を考慮するため 3 種 のダイを用い, 毛管粘度計によりライオトロピック液晶の粘弾特 性のせん断および濃度依存性を測定した。そして, 弾性パラメ一 タ一間の相互関係, すなわち 討した．用いたライオトロピック液晶は，ヒドロキシプロピルセ ルロースの酢酸濃厚溶液である。

\section{2. 方}

法

\section{$2 \cdot 1$ 試 料}

市販ヒドロキシプロピルセルロース (HPC, 東京化成工業KK製) をそのまま用いた，固有粘度 (メタノール， $\left.25^{\circ} \mathrm{C}\right)^{15}$ )を基に求め た重量平均分子量は $9.3 \times 10^{4}$ である。溶媒として市販一級酢酸 （和光純薬工業KK製）を 1 回蒸留して用いた.

\section{$2 \cdot 2$ 濃厚溶液の調整}

真空下, $60^{\circ} \mathrm{C}$ で約 24 時間乾燥した HPC の所定量 $(\mathrm{g})$ に酢酸 $(\mathrm{g})$ を加え，摫はん器により室温で溶解させた。ただし，HPCを精 量する際，大気中の水分が HPC に吸着するのを最少限に抑える ために以下の手段を用いた。すなわち, 乾燥 HPC を重量既知の 共栓付三角フラスコ中で粗量し, それを真空下, $60^{\circ} \mathrm{C}$ で再度 24 時 間乾燥後, すばやく栓をし, 精量した，液晶を形成する高濃度で は溶解に約 3 力月を要した.

\section{$2 \cdot 3$ 毛管粘度法}

自作の定荷重押出し型毛管粘度計を用いた。 装置の詳細は前報 に示した ${ }^{16)}$. 前報と異なる点は, Bagley 補正を行うため 3 種の ダイを用いたてとである。 それらダイは，内径（D）がいずれあ $0.5 \mathrm{~mm}$ ，長さ $(L)$ と $D$ との比 $L / D$ が $10,20,40$ の 3 種である. 真の応力 $\sigma_{\text {true }}$ は次式により求めた.

$$
\sigma_{\text {true }}=\frac{D \cdot \Delta P}{4(L+\nu \cdot D)}
$$

ここで, $\Delta P$ はダイ末端間の圧力差である. 見かけのせん断速度 $\dot{\gamma}$ はピストンの落下速度を測定し，次式により算出した。

$$
\dot{\gamma}=\frac{32 Q}{\pi D^{3}}
$$

ここで，Q は体積流量 $\left(\mathrm{cm}^{3} / \mathrm{sec}\right)$ である，せん断粘度 $\eta$ は， $\sigma_{\text {true }}$ と $\dot{\gamma}$ の比として求めた。 その再現性は $4 \%$ 以下であった. ダイスウェル $B$ は前報 ${ }^{16)}$ と同様に, 流出物径を写真撮影し求め た.

実験はすべて $25^{\circ} \mathrm{C} に$ 扔いて行った。

\section{3. 結 果と考 察}

\section{3·1 Bagley 補正およびせん断粘度 $\eta$}

異方相溶液における圧力差 $\Delta P$ と, せ九断速度 $\dot{\gamma}$ の関係の一例 を Fig. 1 亿示す. $\Delta P$ は $\dot{\gamma}$ の増大とと屯に増大し, 同一 $\dot{\gamma}$ で比 較すれば, $L / D$ が大なほど $\Delta P$ は大であった. この傾向は等方 相溶液にあみられ，常識的結果であった. Fig. 1 の結果に基づい て Bagley プロットしたのが Fig. 2 である. ダイの $L / D$ が10か ら40の間では, $\Delta P$ と $L / D$ の間にほぼ直線性が成立した。 その直 線性は等方相溶液 ${ }^{10}$ 抢よびサーモトロピック液晶 ${ }^{14)}$ で成立するて とは知られているが，ライオトロピック液晶においてる Bagley により提案されたダイ流入部での末端補正が適用可能であるとと を Fig. 2 は示す. なお, Fig. 2 亿扔いて, 各字における直線が $\Delta P$ 軸之交差する点から流入圧損失 $\Delta P_{\mathrm{ent}}$ が, また横軸之の交差 点の絶対值から Bagley 補正係数レが求まる.

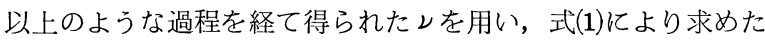

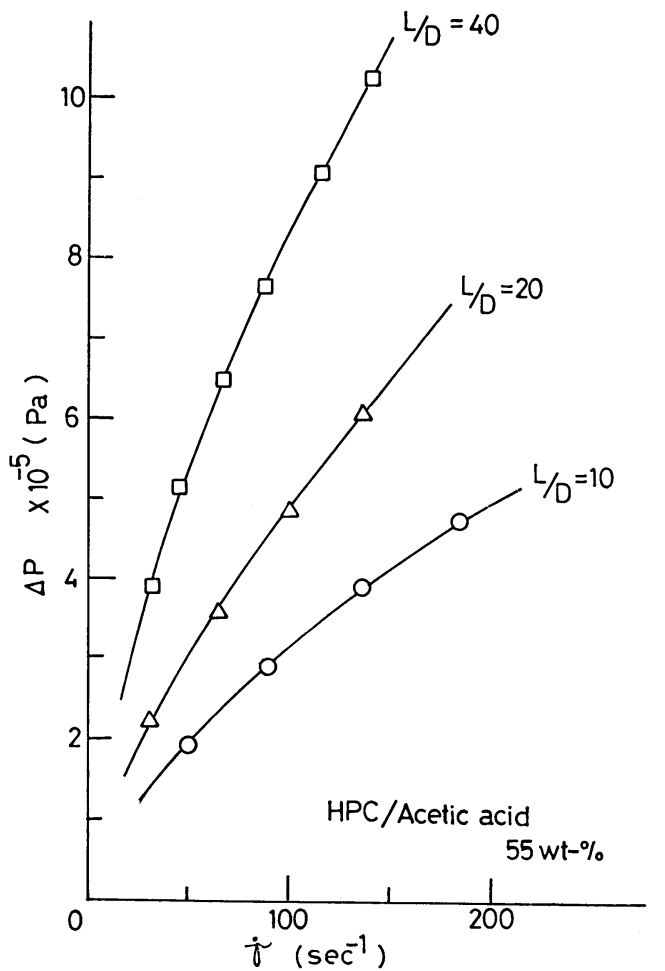

Fig. 1 Pressure drop across die vs. shear rate for 55 wt $\%$ solution of HPC in acetic acid at $25^{\circ} \mathrm{C}$. 


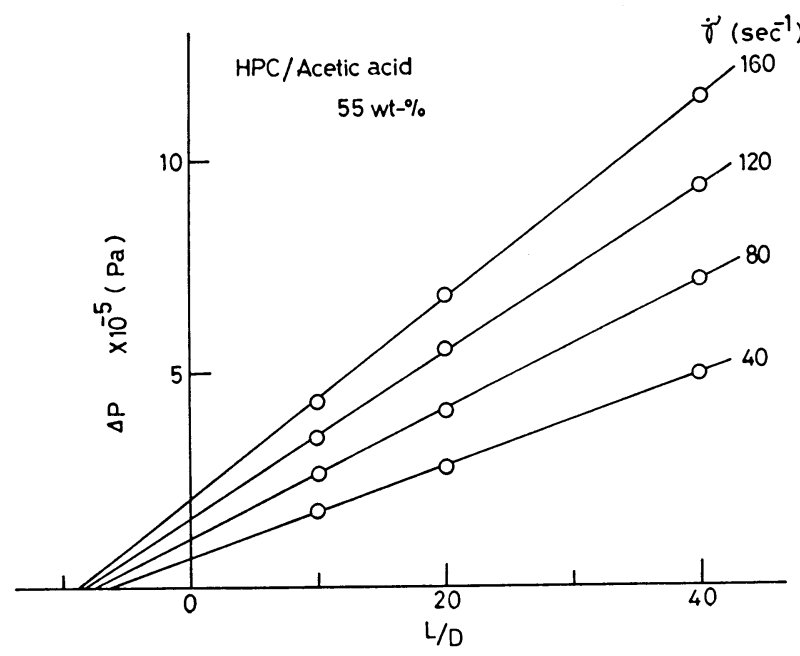

Fig. 2 Typical Bagley plots for $55 \mathrm{wt} \%$ solution of HPC in acetic acid.

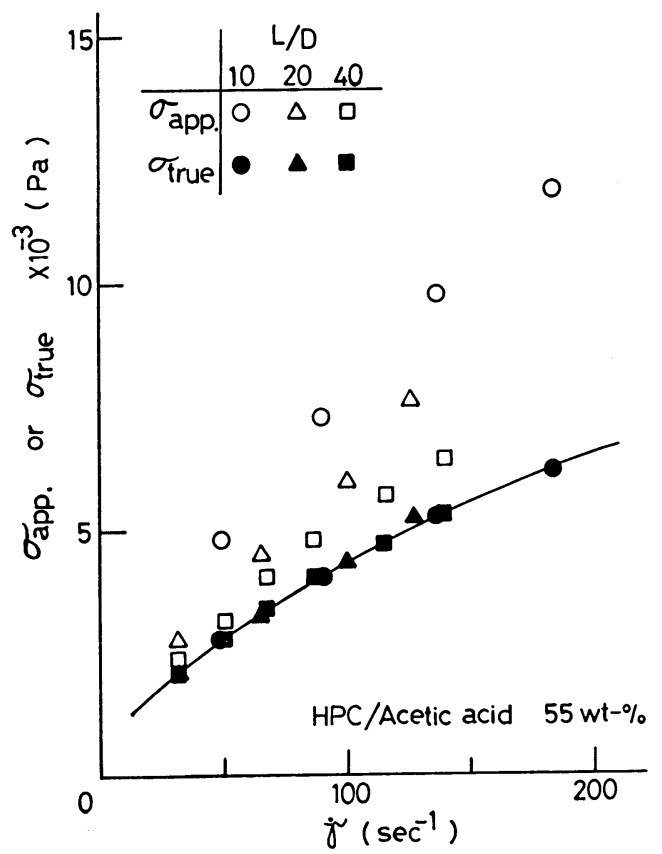

Fig. 3 Apparent and true shear stresses vs. shear rate for $55 \mathrm{wt} \%$ solution of HPC in acetic acid.

真のせん断応力 $\sigma_{\text {true }}$ の結果を Fig. 3 亿示す. Fig. 3 から明ら かなように，見掛けの応力は真の応力よりかなり大きかった。 て の結果は次の事を示唆する.すすなわ，(1)単独の長いダイを用い て真の応力を測定するためには，ダイの $L / D$ が80前後必要であ る.また, (2)せん断速度範囲に注意すべきで, せん断速度が増大 するほど必要なダイの $L / D$ は大きくなる.

Fig. 4 は各濃度におけるクの $\dot{\gamma}$ 依存性を示す。浅田ら ${ }^{17)}$ は液 晶の流動カーブについて一つのモデルを提案しているが, 25, 35, $45 \mathrm{wt} \%$ 溶液は上記モデルの第二領域，また $50,55 \mathrm{wt} \%$ 溶液は 第一領域に相当するととを Fig. 4 は示す. Fig. 5 には各 $\dot{\gamma}$ にお けるクの濃度依存性を示す，予想されたように極大，極小が生じ， ライオトロピック液晶特有の結果であった．ただし，極大の位置 を $30 \mathrm{wt} \%$ 前後としたととには定量的根拠はない. しかし, 流動

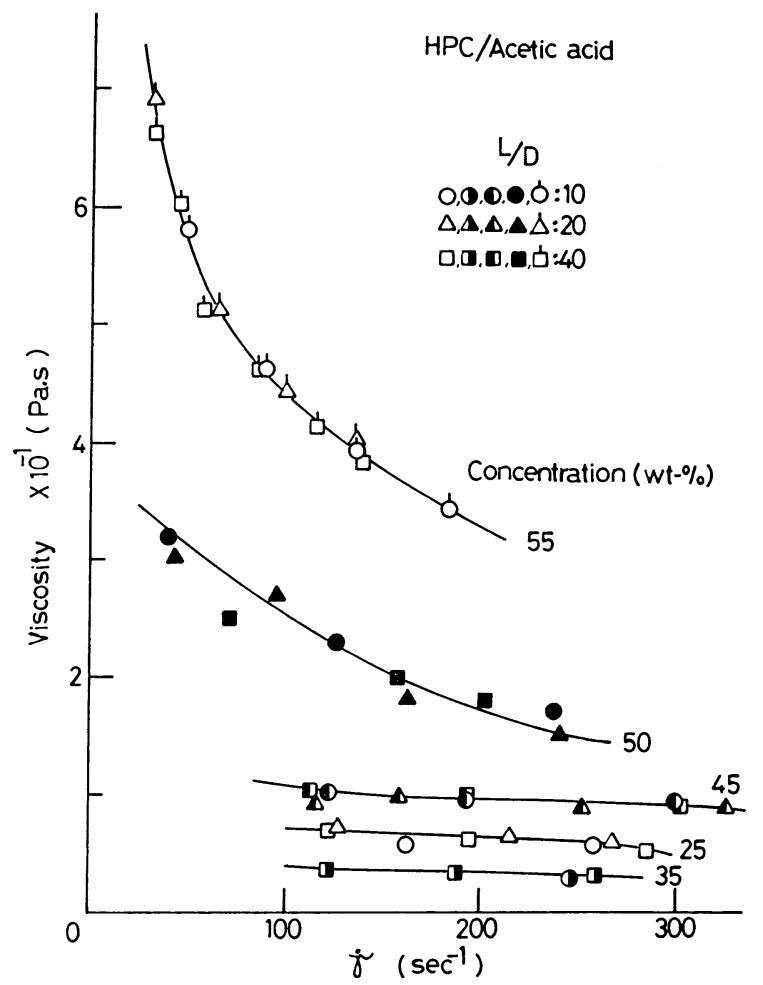

Fig. 4 Flow curves for solution of HPC in acetic acid at $25^{\circ} \mathrm{C}$.

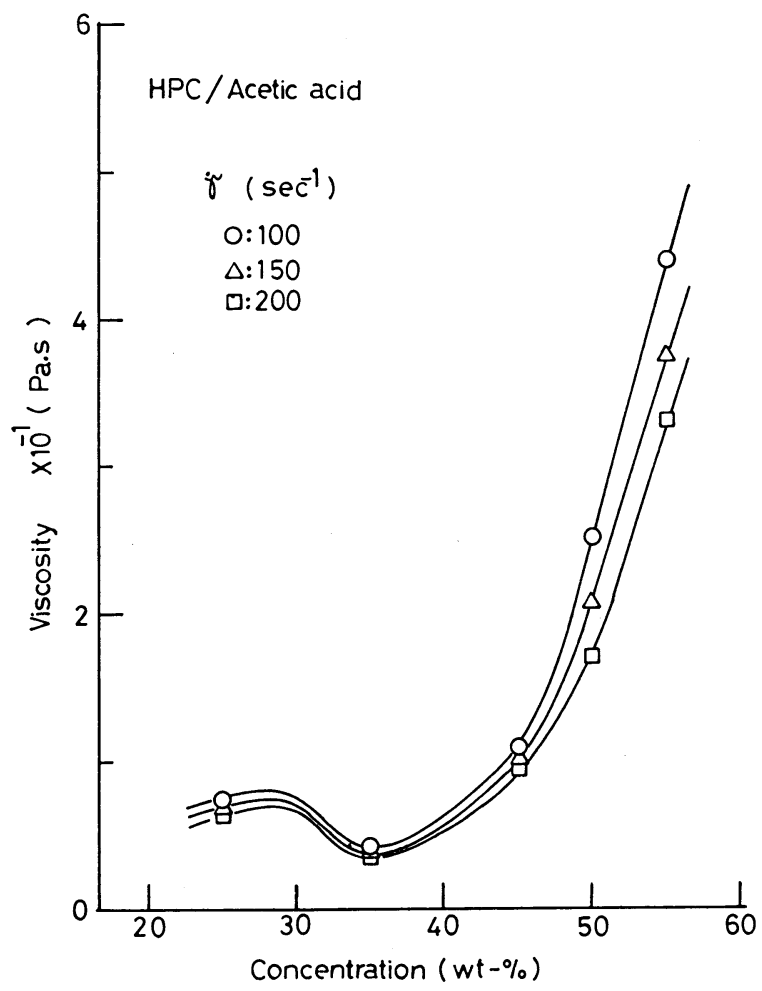

Fig. 5 Concentration dependence of shear viscosity for solution of HPC in acetic acid.

状態を観察すると， $25 \mathrm{wt} \%$ 溶液は透明であり， $35 \mathrm{wt} \%$ 溶液は 少し濁りが生じていたので, 前者は等方相, 後者は異方相溶液と 判断した。 $25 \mathrm{wt} \%$ と $35 \mathrm{wt} \%$ の間で相転移が生じていたととに 


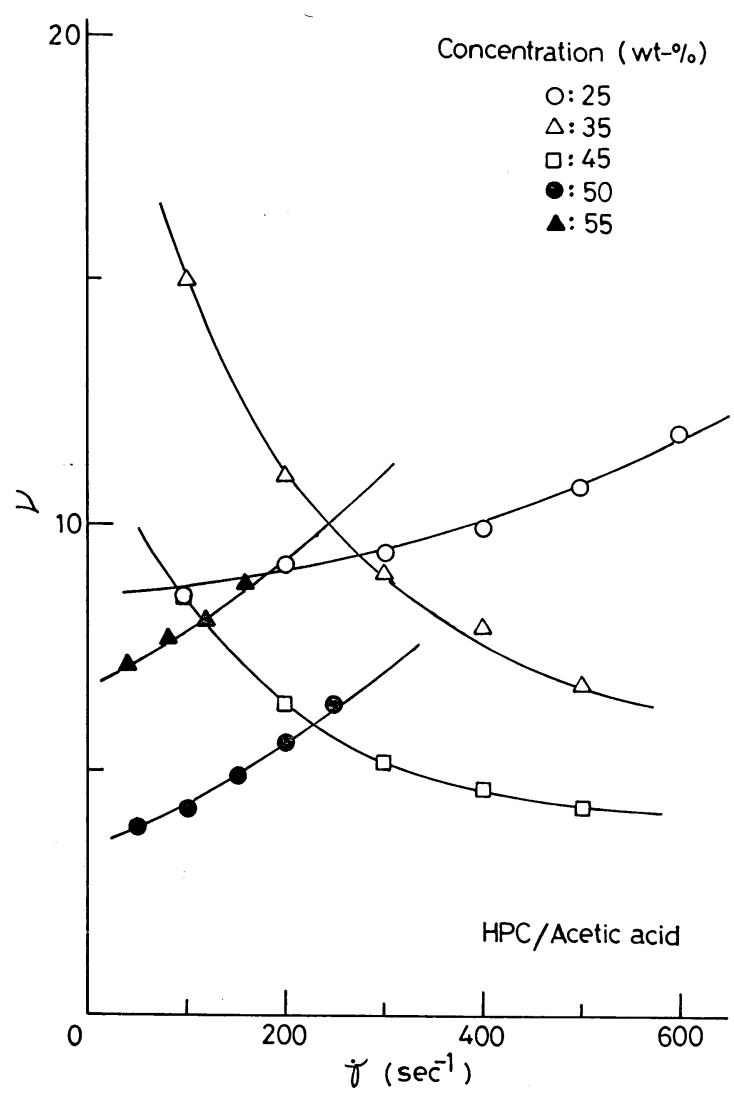

Fig. 6 Bagley end correction vs. shear rate for solution of $\mathrm{HPC}$ in acetic acid at $25^{\circ} \mathrm{C}$.

なるので, $30 \mathrm{wt} \%$ 前後に極大を図示した。なお，同一系の静止

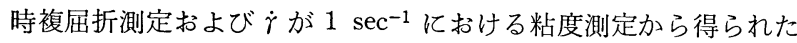
相転移濃度 (A 点) は $30.3 \mathrm{wt} \%$ であった ${ }^{18)}$.

$3 \cdot 2$ 弾性パラメーター

Fig. 2 の Bagley プロットより得られた Bagley 補正係数レを

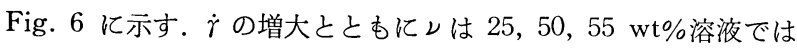
増大したが，35，45 wt\%溶液では逆に減少した。等方相系では,

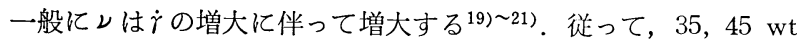

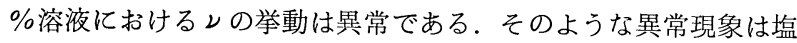
化ビニル系ポリマー融液 ${ }^{22)}$ と, マルトースシロップ12)についての 報告がある程度で, 極めてまれであった. 塩化ビニルは完全に均 一な融液でなく，微結晶を残存させたままの二相系であるとの考 えがある ${ }^{23)}$. 䇾島 ${ }^{22)}$ らはその考えに立脚して, 流体の不均一さが その異常現象の原因と考えた，著者もその考えに従う之，Fig. 6

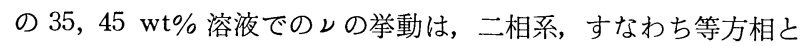
液晶相の混合系であるととが原因となっているものと考えられる， しかし, Fig. 5 のクの濃度依存性から得られた知見からすると， $35 \mathrm{wt} \%$ は混合系と思われるが, $45 \mathrm{wt} \%$ 溶液は単一液晶相へ転移 が完了しているととになるので, עとクの挙動との対応は完全で ない.

Fig. 7 にンの濃度依存性を示すが, Fig. 5 と比較するとその 違いが明らかである．すなわち，極小を示す濃度が異なる。屯し， Fig. 7 の極大, 極小屯クの場合之同様に相転移之の関連から説明 できるとすれば, Fig. 7 では 45 wt\%溶液は混合系である. この ように, $45 \mathrm{wt} \%$ 溶液が混合相か単一液晶相か, クとレの結果の

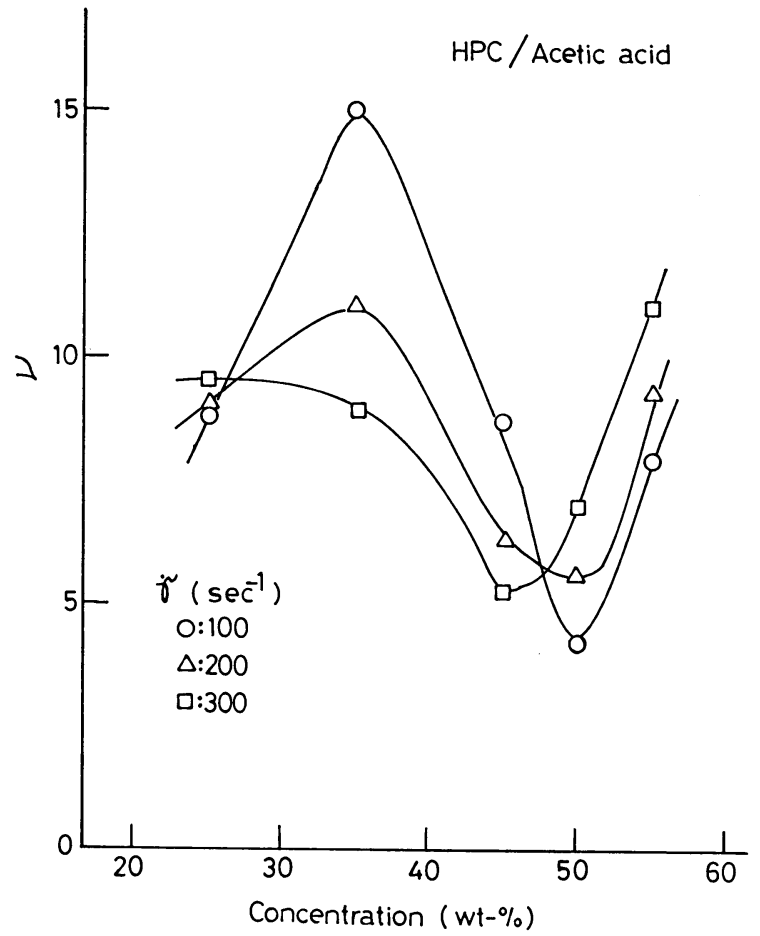

Fig. 7 Concentration dependence of Bagley end correction for solution of HPC in acetic acid.

対応に問題がある，乙こで， $45 \mathrm{wt} \%$ 溶液は混合相であるとすれ ば，すなわちレの異常現象は相の状態（単一相むしくは混合相） に依存するとすれば，ガラス繊維その他の充てん材複合系におい てあ, ある特定せん断条件範囲でעの減少する現象が見られる之

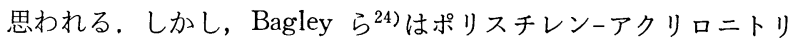

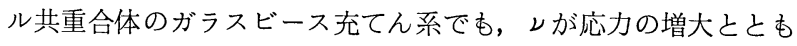
に増大する結果を報告している. 故に, 相の状態に 存するとの推定は妥当とは思われない.

以上のように, 本研究の結果だけからでは $\nu$ 異常挙動, およ びンとクの濃度依存性の不一致の原因を明確に説明できない。他 の液晶系の結果む集積する必要がある.

Fig. 8 および Fig. 9 亿, 流入圧損失 $\Delta P_{\text {ent }}$ の $\dot{\gamma}$ および濃度 依存性をそれぞれ示す. $\Delta P_{\text {ent }}$ は $\nu$ とは異なり，いずれの濃度に

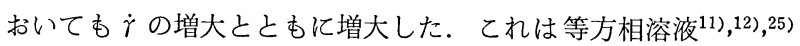
や融液 $\left.{ }^{26)}, 27\right)$, および液晶融液 ${ }^{14)}$ の結果と定性的には一致する。

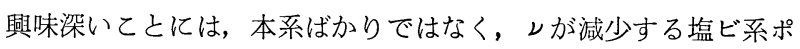

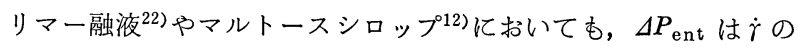
増大ととあに単調に増大した. このととは $\Delta P_{\text {ent }}$ が流体の均一, 不均一性依存しないととを示唆する。 また, Fig. 9 の濃度依存 性は Fig. 5 のクのそれ之類似であった.

以上はダイ流入部での弾性パラメーターの結果であったが, 次 にダイ流出部での弾性パラメーター, ダイスウェル B の真の応力 $\sigma_{\text {true }}$ 依存性を Fig. 10 亿示す. Fig. 10 だけは $\sigma_{\text {true }}$ に対して プロットした，それは $\dot{\gamma}$ でプロットすると，ダイの $L / D$ 依存性 が顕著にみられたためである。等方相溶液である $25 \mathrm{wt} \%$ 溶液の $B$ は， $\sigma_{\text {true }}$ の増大とと屯に単調に増大し常識的結果であった。 しかし, $35 \mathrm{wt} \%$ 以上の液晶のBは, 逆に $\sigma_{\mathrm{true}}$ の増大とと屯に 減少し, そしてある応力以上で平坦部を示す傾向がみられた。 


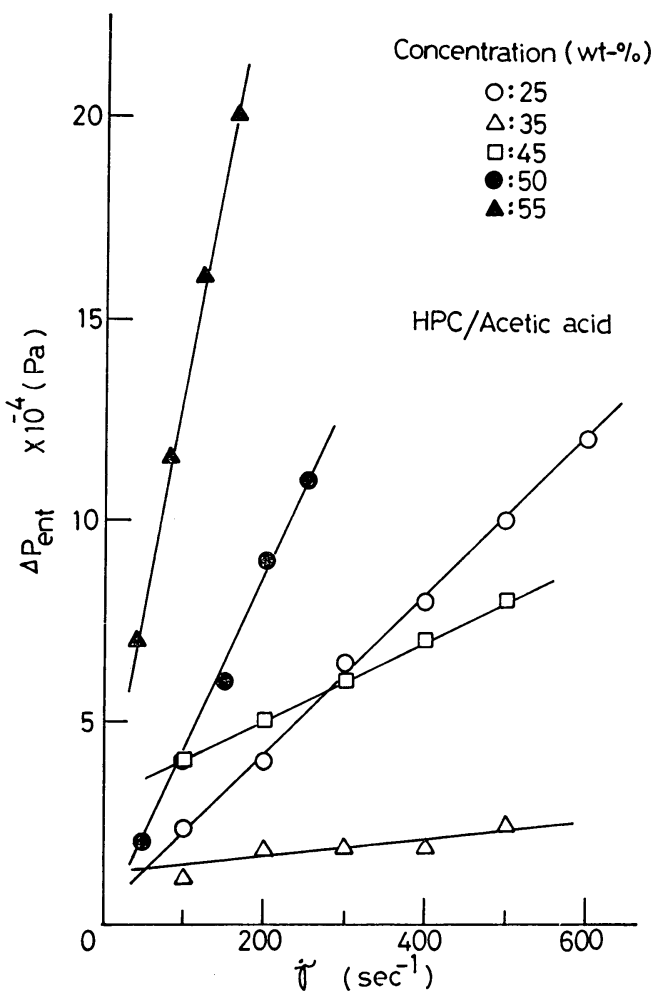

Fig. 8 Entrance pressure loss vs. shear rate for solution of $\mathrm{HPC}$ in acetic acid at $25^{\circ} \mathrm{C}$.

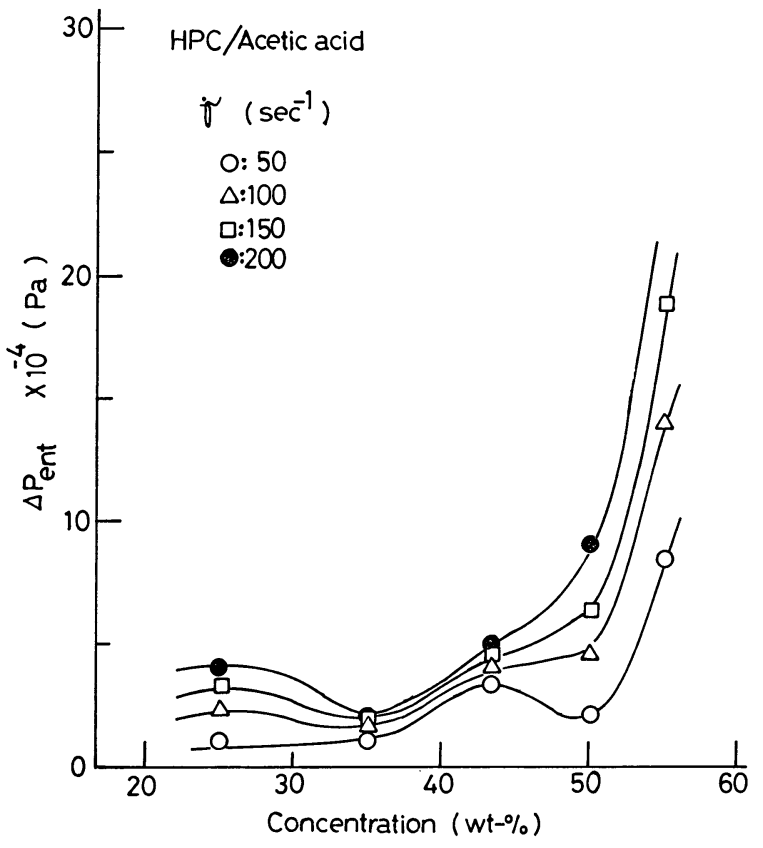

Fig. 9 Concentration dependence of entrance pressure loss for solution of HPC in acetic acid.

Fig. 10 にみられる他の特徵は, ライオトロピック液晶の $B$ はサ 一モトロピック液晶のそれほど小さくないという点である. Fig. 11 は， $\sigma_{\text {true }}$ が $5.0 \times 10^{2}(\mathrm{~Pa})$ におけるBの濃度依存性を示す. この結果は, Fig. 5 のわおよ゙ Fig. 9 の $\Delta P_{\text {ent }}$ の結果とよく対 応する.

$$
3 \cdot 3 \text { 弾性パラメーター間の関係 }
$$

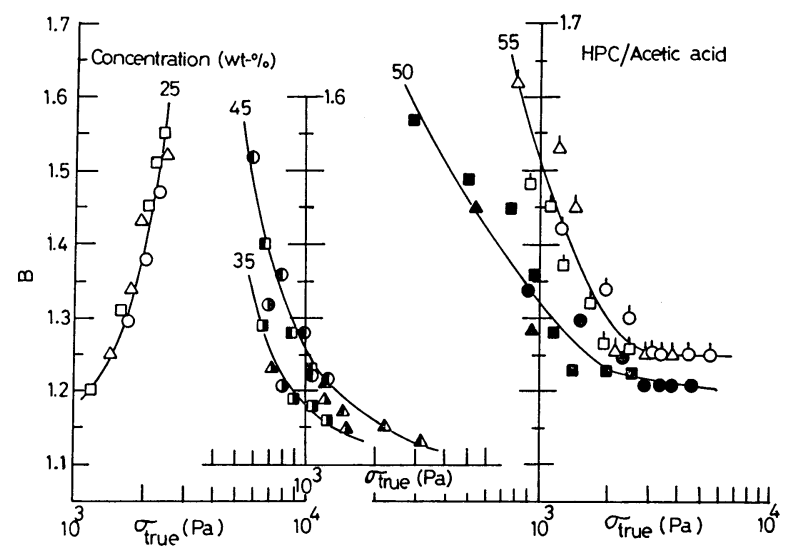

Fig. 10 Die swell vs. shear stress for solution of HPC in acetic acid.

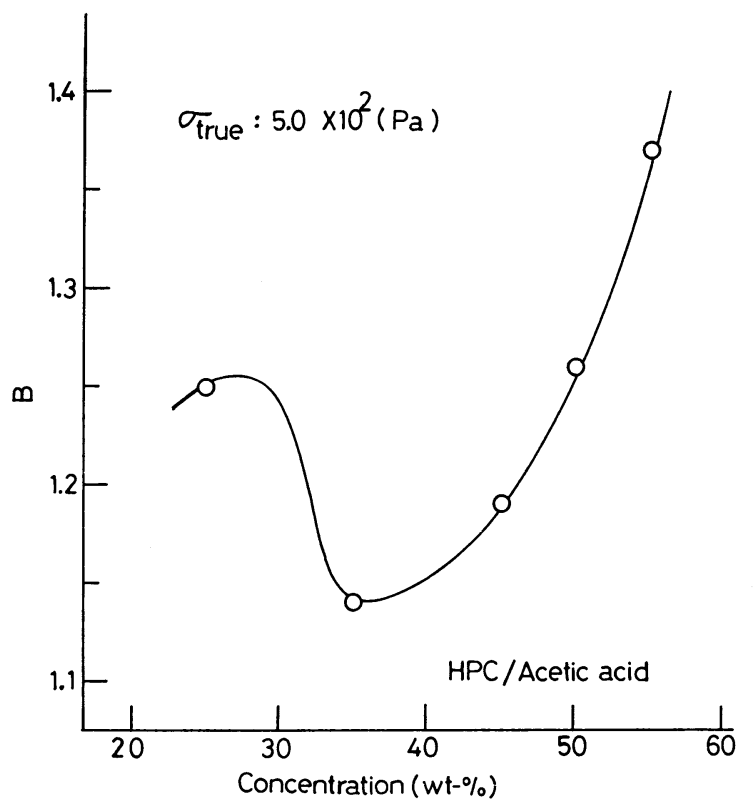

Fig. 11 Concentration dependence of die swell for solution of HPC in acetic acid.

$\nu$ と $B$ 抢よび $\Delta P_{\text {ent }} B$ の関係を, 以下で検討する. Philippoff $\zeta^{28)}$ は等方性溶液の場合, $\nu$ と回復性せん断ひずみ $S_{\mathrm{R}}$ との間に, 次の関係が成立すると報告した。

$$
\nu \propto S_{\mathrm{R}}
$$

また, Tanner ${ }^{29}$ による $B$ の理論では,

$$
B^{3} \propto S_{\mathrm{R}}
$$

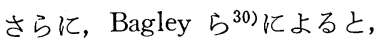

$$
B^{2} \propto S_{\mathrm{R}}
$$

がそれぞれ成立する. 故に, 式(3)と(4)および式 (3)と (4) から次式 がそれぞれ誘導される.

$$
\nu \propto B^{3}
$$

または，

$$
\nu \propto B^{2}
$$

実験的には， $\nu$ 屯しは $\Delta P_{\mathrm{ent}}$ と $B$ の間に正の相関があるとと 


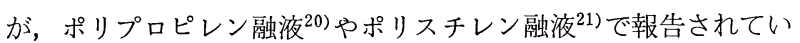

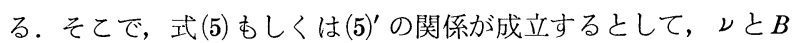
をそれぞれ対数プロットすると, 直線関係が得られ，その傾きか らBのべき指数が求まるととになる。乙とでは $L / D$ が 40 のダイ

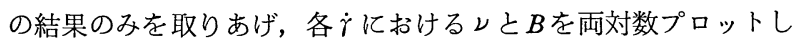
た。すると, 等方相溶液のみならず液晶相溶液においても, 次の 関係がほぼ成立した。

$$
\nu \propto B^{n}
$$

25, 35, $45 \mathrm{wt} \%$ 溶液の $n$ は正の值で，それぞれ $0.95,5.5,5.2$ であった。しかし，50, $55 \mathrm{wt} \%$ 溶液では比較的低 $\dot{\gamma}$ 領域のみで 直線関係が得られ， $n$ は負の值を示した。等方相溶液の場合です ら, $n$ の值が Bagley らの式(5)'から予测される值, 2 の半分以下 であり，等方相高分子液体に関する報告とは相当異なっている. $n$ の実験結果の物理的意味づけは，今後に残された問題である.

$\nu$ の場合之同様に, $\Delta P_{\text {ent }}$ と $B$ の関係屯式(6)と類似と思われる ので，上記と同様の手順に従い両対数プロットするとほぼ直線関 係が得られた。

$$
\Delta P_{\text {ent }} \propto B^{n^{\prime}}
$$

Fig. 8 と Fig. 10 の比較から容易に推察されるように, 等方相溶 液 $25 \mathrm{wt} \%$ 溶液のみ $n^{\prime}$ は， 3.55 と正の值を示したが，他の溶液 はすべて負の $n^{\prime}$ を示した. 式(6)同様式(7)においても， $n^{\prime}$ の物理 的意味の解明が必要である.

White ${ }^{31)}$ は, 弾性パラメーターとして $\Delta P_{\text {ent }}$ ではなく $\Delta P_{\text {ent }} /$ $\sigma_{\text {true }}$ を用いているが, 今後, 彼のパラメーターを含めどのよう なパラメーターが，毛管流動における液晶の弾性を正しく反映す るのか検討する必要がある.さらに，本研究で得られた関係がラ イオトロピック液晶全般にわたって, 普遍性のあるむのか否かの 検討あ必要である。

\section{4. 結}

\section{論}

1）せん断粘度はライオトロピック液晶にみられる常識的挙動 を示した。

2）弾性パラメーターの一つと考えられる Bagley 補正係数 のせん断速度依存性は, 濃度に大きく依存した。また, 依存性はせん断粘度のそれと同様に極大，極小を示したが，極小 の位置は一致しなかった。他の弾性パラメーター, 流入在損失 $\Delta P_{\text {ent }}$ はいずれの濃度においてもせん断速度の増大とともに増大 した。 その濃度依存性はせん断粘度のそれと定性的に一致した。 ダイ流出部でみられるダイスウェル $B$ は, 等方相溶液の場合のみ 応力の増大ととむに増大したが, 液晶のそれは逆に減少した.

3） $\nu$ とおよび $\Delta P_{\text {ent }}$ よ $B$ の間に，ほぼ次の関係がそれぞれ 成立した。

$$
\begin{aligned}
& \nu \propto B^{n} \\
& \Delta P_{\text {ent }} \propto B^{n^{\prime}}
\end{aligned}
$$

しかし，なお他の液晶系のデータの集積が必要である.

本研究の一部は, 昭和60年10月第33回レオロジー討論会(米沢) において発表した。

$$
\text { 文献 }
$$

1) Baird, D.G., "Liquid Crystalline Order in Polymers",
A. Blumstein Ed., p. 237 (1978), Academic press, New York.

2) Wissbrun, K.F., J. Rheol., 25, 619 (1981).

3) White, J.L., J. Appl. Polym. Sci. Appl. Polym. Symp., 41, 241 (1985).

4) Baird, D.G., J. Rheol., 24, 465 (1980).

5) Kiss, G., and R.S. Porter, J. Polym. Sci. Polym. Phys. Ed., 18, 361 (1980).

6) Aoki, H., J.L. White, and J.F. Fellers, J. Appl. Polym. Sci., 23, 2293 (1979).

7) Suto, S., J.L. White, and J.F. Fellers, Rheol. Acta, 21, 62 (1982).

8) Baird, D.G., A. Gotsis, and G. Viola, Polymer Preprints, 24(2), 292 (1983).

9) Walters, K., "Rheometry", Chap. 5 (1975), Chapman and Hill, London.

10) Tadmor, Z., and C.G. Gogos, "Principles of Polymer Processing”, Chap. 13 (1979), John Wiley, New York.

11) LaNieve III, H.L., and D.C. Bogue, J. Appl. Polym. Sci., 12, 353 (1968).

12) Boger, D.V., and R. Binnington, Trans. Sco. Rheol., 21, 515 (1977).

13）例えば, Kao, C.H., and D.G. Baird, Polym. Eng. Sci., 22, 521 (1982).

14) Jerman, R.E., and D.G. Baird, J. Rheol., 25, 275 (1981).

15) Wirick, M.G., and M.H. Waldman, J. Appl. Polym. Sci., 13, 2735 (1969).

16) Suto, S., R. Ito, and M. Karasawa, Polym. Commun., 26, 335 (1985).

17) Onogi, S., and T. Asada, "Rheology", G. Astarita, G. Marrucci, and L. Licolais Eds., p. 127 (1980), Plenum, New York.

18）Suto, S., 未発表データ.

19）荒井定吉, 青山 宏, 鈴木 功, 工化誌， 63，418（1960).

20）藤山光美, 栗屋 裕, 材料, 20, 616 (1971).

21) Pena, J.J., G.M. Guzman, and A. Santamaria, Polym. Eng. Sci., 21, 307 (1981).

22）䇾島信雄, 小林茂勝, 志村光久, 木下洋一, 高分子化学, 28, 953 (1971).

23) Pezzin, G., G. Ajroldi, and C. Garbuglio, Rheol. Acta, 8, 304 (1969).

24) Agarwal, P.K., E.B. Bagley, and C.T. Hill, Polym. Eng. Sci., 18, 282 (1978).

25) Oliver, D.R., W. Macsporran, and B.M. Hiorns, $J$. Appl. Polym. Sci., 14, 1277 (1970).

26) Han, C.D., AIChE. J., 17, 1480 (1971).

27) Carter, D.H., and J.A. Cuculo, J. Polym. Sci. Polym. Phys. Ed., 22, 1 (1984).

28) Philippoff, W., and F.H. Gaskins, Trans. Soc. Rheol., 2, 263 (1958).

29) Tanner, R.I., J. Polym. Sci., A-2, 8, 2067 (1970).

30) Mendelson, R.A., F.L. Finger, and E.B. Bagley, Trans. Soc. Rheol., 16, 669 (1972).

31) White, J.L., J. Appl. Polym. Sci. Appl. Polym. Symp., 20, 155 (1973). 